\title{
Korelasi Kadar Albumin Serum dengan Persentase Edema pada Anak Penderita Sindrom Nefrotik dalam Serangan
}

\author{
Novina, Dida Akhmad Gurnida, Nanan Sekarwana \\ Departemen Ilmu Kesehatan Anak Fakultas Kedokteran Universitas Padjadjaran \\ Rumah Sakit Dr. Hasan Sadikin Bandung
}

\begin{abstract}
Abstrak
Sindrom nefrotik (SN) merupakan kelainan glomerulus yang ditandai proteinuria masif, hipoalbuminemia, edema, dan hiperlipidemia. Penelitian ini bertujuan untuk mengetahui hubungan antara kadar albumin serum dan persentase edema pada anak penderita SN dalam serangan. Suatu uji analitik korelasional rancangan crosssectional dilakukan selama bulan Agustus 2009 sampai Januari 2010. Subjek penelitian adalah anak penderita SN dalam serangan, usia 1-14 tahun, berobat ke poliklinik atau dirawat di Rumah Sakit Dr. Hasan Sadikin dan RS Jejaring (RSU Cibabat dan RSU Ujung Berung). Persentase edema dihitung dengan mengurangi total body water (TBW) anak saat sakit dengan TBW ideal, kemudian hasilnya dipersentasekan dengan TBW ideal. Analisis statistik menggunakan Uji korelasi Spearman. Pada penelitian ini didapatkan 29 subjek terdiri atas 26 laki-laki dan 3 perempuan. Kadar albumin serum rata-rata 1,45 g/dL dan persentase edema 21,6\%. Hasil Uji korelasi Spearman menunjukkan hubungan yang sangat bermakna $(\mathrm{p}=0,006)$ antara kadar albumin serum dan persentase edema $(\mathrm{r}=-0,501)$. Simpulan, terdapat hubungan negatif antara kadar albumin serum dan persentase edema pada anak penderita SN dalam serangan. [MKB. 2015;47(1):55-9]
\end{abstract}

Kata kunci: Kadar albumin serum, persentase edema, sindrom nefrotik dalam serangan

\section{Correlation Between Serum Albumin Levels and Percentage of Edema during Nephrotic Stage in Children with Nephrotic Syndrome}

\begin{abstract}
Nephrotic syndrome (NS) is a glomerular disorder characterized by massive proteinuria, hypoalbuminemia, edema, and hyperlipidemia. The aim of this study was to evaluate the correlation between serum albumin levels and percentage of edema during nephrotic stage in children with NS. Cross-sectional design with correlational analytic was used in this study. The subjects of this study were outpatients and inpatients with NS during nephrotic stage, aged between 1 and 14 years old, admitted to Dr. Hasan Sadikin General Hospital Bandung, Cibabat Hospital, and Ujung Berung Hospital from August 2009 to January 2010. Percentage of edema was calculated by substracting total body water (TBW) during illness to ideal TBW, then divided the result by ideal TBW. Subjects were 29 children, consisted of 26 boys and 3 girls. Mean serum albumin levels was $1.45 \mathrm{~g} / \mathrm{dL}$ and percentage of edema was $21.6 \%$. Analysis using Spearman correlation test showed a highly significant correlation $(p=0.006)$ between serum albumin levels and percentage of edema in children with NS during nephrotic stage $(r=-0.501)$. In conclusion, there is a negative correlation between serum albumin levels and percentage of edema during nephrotic stage in children with NS. [MKB. 2015;47(1):55-9]
\end{abstract}

Key words: Nephrotic syndrome, nephrotic stage, percentage of edema serum albumin levels

Korespondensi: Novina, dr., Sp.A., M. Kes, Departemen Ilmu Kesehatan Anak Fakultas Kedokteran Universitas Padjadjaran/ Rumah Sakit Dr. Hasan Sadikin Bandung Jalan Pasteur No. 38 Bandung, mobile 08122009757, e-mail: novina.ade@gmail.com 


\section{Pendahuluan}

Sindrom nefrotik (SN) merupakan suatu kelainan yang memerlukan perhatian khusus mengingat penyakitnya dapat bersifat kronik serta evaluasi dan penatalaksanaannya yang sangat kompleks, meskipun angka kejadiannya jarang. ${ }^{1}$

Sindrom nefrotik ditandai dengan edema, hipoalbuminemia $\leq 2,5 \mathrm{~g} / \mathrm{dL}$, proteinuria masif $>40 \mathrm{mg} / \mathrm{m}^{2} / \mathrm{jam}$ (atau rasio protein/kreatinin pada urin sewaktu $>2 \mathrm{mg} / \mathrm{mmol}$ atau dipstik $\geq 2+$ ), dan dapat disertai hiperkolesterolemia. ${ }^{2,3}$ Diperkirakan insidensi SN pada anak sebesar 2-7 per 100.000 dan prevalensi sebesar 12-16 per 100.000 anak $^{3,4}$ Keluhan utama seorang anak yang menderita SN adalah edema. Edema timbul karena terdapat akumulasi cairan ekstraselular pada jaringan interstitial. ${ }^{4,5}$ Kelsch dan Sedman ${ }^{6}$ mengemukakan bahwa anak penderita sindrom nefrotik dalam serangan, edema mulai timbul bila kadar albumin $<2,7 \mathrm{~g} / \mathrm{dL}$ dan selalu ditemukan apabila kadar albumin $<1,8 \mathrm{~g} / \mathrm{dL}$. Vande Walle dkk. ${ }^{7}$ menyatakan bahwa kadar albumin pada anak dengan SN lesi minimal memperlihatkan gejala edema berkisar 1,1-1,9 g/dL, sedangkan anak dengan lesi nonminimal berkisar 0,6-1,0 g/ dL.

Sampai saat ini belum terdapat penelitian tentang hubungan antara kadar albumin serum dan persentase edema pada anak penderita SN dalam serangan. Selama ini persentase edema anak penderita SN hanya perkiraan dan belum pernah dilakukan penelitian untuk membuktikan keabsahannya. Berat badan kering diperlukan untuk menghitung dosis kortikosteroid secara tepat dalam pengobatan SN namun berdasarkan anamnesis juga tidak dapat diandalkan karena orangtua terkadang lupa atau jawaban tidak akurat. Pada penatalaksanaan sindrom nefrotik, kortikosteroid telah dipergunakan sejak tahun 1950 dan sampai saat ini masih merupakan terapi utama untuk mengobati SN pada anak. Pemberian kortikosteroid menurunkan angka kematian dari 35\% menjadi $3 \%{ }^{8}$ Pemberian kortikosteroid dengan dosis tepat sesuai berat badan kering anak penting dalam menangani anak penderita SN karena toksisitas pemberian kortikosteroid berpotensi mengancam hidup sehingga risiko dan manfaat terapi harus terus dievaluasi.

Penelitian ini bertujuan mengetahui korelasi antara kadar albumin serum dan persentase edema pada penderita sindrom nefrotik dalam serangan. Penelitian mengenai korelasi kadar albumin serum dengan persentase edema untuk menghitung berat badan kering anak penderita sindrom nefrotik dalam serangan di Indonesia belum pernah dilaksanakan, karena itu peneliti memandang penting untuk mengetahuinya dan diharapkan dapat berguna sebagai tambahan ilmu pengetahuan khususnya untuk menentukan tatalaksana selanjutnya.

\section{Metode}

Penelitian ini merupakan uji analisis korelasional secara cross-sectional terhadap anak usia $\geq 1-14$ tahun dengan SN dalam serangan yang datang ke poliklinik atau dirawat di Departemen Ilmu Kesehatan Anak Rumah Sakit Dr. Hasan Sadikin Bandung dan RS Jejaring (RSU Cibabat dan RSU Ujung Berung) mulai Agustus 2009 hingga Januari 2010. Subjek tidak diikutkan dalam penelitian apabila telah mendapat transfusi albumin dalam waktu 20 hari sebelum pemeriksaan, menderita gangguan gizi saat pemeriksaan, dan menderita penyakit kronik seperti TB paru, keganasan, gagal jantung, sirosis hepatik, gagal ginjal kronik. Penelitian ini sudah mendapatkan persetujuan Komite Etik Penelitian Kesehatan dari Fakultas Kedokteran Universitas Padjadjaran dan Rumah Sakit Dr. Hasan Sadikin Bandung.

Dengan taraf kepercayaan 95\% dan power test $80 \%$ didapatkan besar sampel minimal sebanyak 29 subjek. Pada subjek ini dilakukan anamnesis, pemeriksaan fisis, dan pengambilan darah vena untuk menentukan kadar albumin serum yang dilakukan pada saat kedatangan di rumah sakit. Kadar albumin serum diukur menggunakan metode colorimetric dengan brom cresol green. Persentase edema dihitung dengan mengurangi total body water (TBW) anak saat sakit dengan TBW ideal, kemudian hasilnya dipersentasekan dengan TBW ideal. Berat badan ideal didapatkan dari kurva WHO Child Growth Standard ${ }^{9}$ berdasarkan tinggi badan anak. TBW dihitung menggunakan rumus Mellits-Cheek. ${ }^{10}$ Rumus Mellits-Cheek ${ }^{10}$ untuk menghitung TBW pada anak laki-laki: volume (liter) $=-1,927+0,465$ $\mathrm{x}$ berat badan $(\mathrm{kg})+0,045 \mathrm{x}$ tinggi badan $(\mathrm{cm})$, bila tinggi badan $\leq 132,7 \mathrm{~cm}$; volume (liter)= $-21,993+0,406 \times$ berat badan $(\mathrm{kg})+0,209 \times$ tinggi badan $(\mathrm{cm})$, bila tinggi badan $\geq 132,7 \mathrm{~cm}$. Pada anak perempuan volume (liter) $=0,076+0,507$ $\mathrm{x}$ berat badan $(\mathrm{kg})+0,013 \mathrm{x}$ tinggi badan $(\mathrm{cm})$, bila tinggi badan $\leq 110,8 \mathrm{~cm}$; volume (liter)= $-10,313+0,252 \times$ berat badan $(\mathrm{kg})+0,154 \times$ tinggi badan $(\mathrm{cm})$, bila tinggi badan $\geq 110,8 \mathrm{~cm}$.

Untuk mengetahui korelasi kadar albumin serum dengan persentase edema dipergunakan Uji Rank Spearman dan kemaknaan ditentukan 
Tabel 1 Karakteristik Umum Penderita Sindrom Nefrotik

\begin{tabular}{lccc}
\hline \multicolumn{1}{c}{ Karakteristik } & n & Rata-rata (SB) & Median \\
\hline Usia (tahun) & 29 & $6,8(3,8)$ & 69 \\
Usia onset (tahun) & 29 & $5,6(3,7)$ & 54 \\
TBW (L) & 29 & $14,7(5,6)$ & 13,1 \\
TBW ideal (L) & 29 & $12,1(4,5)$ & 10,7 \\
Jenis kelamin & & & \\
$\quad$ Laki-laki & 26 & & \\
$\quad$ Perempuan & 3 & & \\
Status gizi & & & \\
$\quad$ Kurang & 0 & & \\
$\quad$ Baik & 27 & & \\
$\quad$ Lebih/obes & 2 & & \\
Diagnosis kerja & & & \\
$\quad$ SN sensitif steroid (SNSS) & 29 & & \\
$\quad$ SN resisten steroid (SNRS) & 0 & & \\
\hline
\end{tabular}

Keterangan: $\mathrm{SB}=$ simpang baku

berdasarkan nilai $\mathrm{p}<0,05$. Seluruh perhitungan statistik dikerjakan dengan piranti lunak SPSS version 15.0 for windows tahun 2007, SPSS inc, Chicago-Illinois, USA.

\section{Hasil}

Dari sebanyak 29 anak yang masuk kriteria inklusi berdasarkan jenis kelamin lebih banyak anak laki-laki yaitu 26 dan tiga anak perempuan. Subjek termuda berusia 14 bulan, tertua 13 tahun dengan usia rata-rata 6,8 tahun dan usia rata-rata onset 5,6 tahun. TBW rata-rata adalah 14,7 (SB 5,6) L dan TBW rata-rata ideal 12,1 (SB 4,5) L. Sebagian besar penderita termasuk dalam status gizi baik dan seluruh subjek penelitian termasuk SN sensitif steroid (SNSS). Karakteristik penderita terlihat pada Tabel 1.

Semua penderita SN dalam penelitian ini memperlihatkan edema pada palpebra, dorsum pedis, dan pretibial. Pada anak penderita SN dengan edema anasarka menunjukkan edema di semua lokasi tubuh. Tabel 2 memperlihatkan kadar albumin rata-rata serum dan persentase edema subjek penelitian ini. Kadar albumin ratarata serum 1,45 $(\mathrm{SB} 0,43) \mathrm{g} / \mathrm{dL}$ dengan kadar terendah adalah $0,9 \mathrm{~g} / \mathrm{dL}$ dan tertinggi $2,4 \mathrm{~g} / \mathrm{dL}$. Persentase edema 21,6\% (SB 11,4) dengan nilai terendah adalah $6 \%$ dan tertinggi $46 \%$. Dengan uji statistik variabel yang diukur menunjukkan data tidak berdistribusi normal (nilai $\mathrm{p}<0,05$ ). Dengan Uji korelasi Rank Spearman didapatkan hubungan sangat bermakna $(p=0,006)$ antara kadar albumin dan persentase edema dengan koefisien korelasi $r_{s}=-0,501$.

\section{Pembahasan}

Penelitian ini menunjukkan usia subjek termuda adalah 14 bulan, tertua 13 tahun dengan usia rata-rata 6,8 tahun dan usia rata-rata onset 5,6 tahun. Vogt dan Avner ${ }^{11}$ menyatakan SN terjadi pada usia 2-6 tahun. Menurut Haycock ${ }^{12}$ insidensi tertinggi SN idiopati terjadi pada usia

Tabel 2 Distribusi Kadar Albumin Serum dan Persentase Edema

\begin{tabular}{lccc}
\hline \multicolumn{1}{c}{ Variabel } & n & Rata-rata (SB) & Median \\
\hline Kadar albumin serum (g/dL) & 29 & $1,45(0,43)$ & 1,3 \\
Persentase edema (\%) & 29 & $21,6(11,4)$ & 20 \\
\hline
\end{tabular}

Keterangan: $\mathrm{SB}=$ simpang baku 
2-5 tahun. Sebagian besar penderita memiliki status gizi baik berdasarkan WHO Child Growth Standard 2005.

Semua penderita penelitian ini didiagnosis sindrom nefrotik sensitif steroid (SNSS) sesuai dengan data epidemiologi yang menyatakan 95\% anak SN termasuk SN idiopatik dan laporan the International Study of Kidney Disease in Children (ISKDC) yang menyatakan 78,1\% dari 471 anak SN primer berespons terhadap terapi kortikosteroid dan 91,8\% di antaranya adalah SN lesi minimal.,12-14

Menurut the International Study of Kidney Disease in Children (ISKDC) kriteria laboratorium sindrom nefrotik adalah bila hipoalbuminemia kadar $\leq 2,5 \mathrm{~g} / \mathrm{dL}^{3}$ Pada penelitian semua subjek menunjukkan penurunan kadar albumin serum dengan kadar albumin rata-rata serum 1,45 (SB 0,43) g/dL, kadar terendah 0,9 g/dL, dan tertinggi $2,4 \mathrm{~g} / \mathrm{dL}$. Sesuai dengan pernyataan dari Kelsch dan Sedman ${ }^{6}$ pada anak sindrom nefrotik dalam serangan, edema akan mulai timbul bila kadar albumin $<2,7 \mathrm{~g} / \mathrm{dL}$ dan selalu ditemukan apabila kadar albumin $<1,8 \mathrm{~g} / \mathrm{dL}$. Penelitian Vande Walle dkk. ${ }^{7}$ pada anak dengan SN lesi minimal dan nonminimal menyatakan pada anak yang memperlihatkan gejala edema, dilaporkan kadar albumin pada anak dengan lesi minimal berkisar 1,1-1,9 g/dL, sedangkan anak dengan lesi nonminimal berkisar 0,6-1,0 $\mathrm{g} / \mathrm{dL}$. Hipoalbuminemia pada SN terjadi akibat proteinuria yang disebabkan oleh peningkatan permeabilitas kapiler glomerulus, peningkatan sintesis di hepar tidak mampu mengimbangi kehilangan protein melalui urin. ${ }^{14}$

Persentase edema rata-rata $21,6 \%$ (SB 11,4) dengan nilai terendah adalah $6 \%$ dan tertinggi $46 \%$. Niaudet ${ }^{13}$ menyatakan edema terlihat jelas bila retensi cairan mencapai $3-5 \%$ dari berat badan. Berdasarkan teori underfilled proteinuria masif berlanjut menjadi hipoalbuminemia yang dapat menyebabkan tekanan onkotik menurun. Cairan berpindah dari plasma ke intersisial menyebabkan kontraksi volume darah akibatnya terjadi aktivasi sistem renin, aldosteron, dan angiotensin. Akhirnya terjadi retensi garam dan air sehingga edema pun timbul. ${ }^{1,12}$ Korelasi kadar albumin serum dengan persentase edema menggunakan Uji Rank Spearman menunjukkan hubungan negatif yang bermakna $(p=0,006)$ dengan koefisien korelasi $r_{s}=-0,501$. Artinya, semakin rendah kadar albumin serum semakin besar persentase edema pada anak penderita sindrom nefrotik dalam serangan. Keterbatasan penelitian ini adalah tidak ada data berat badan kering anak setelah remisi karena keterbatasan waktu untuk menunggu terjadinya remisi pada setiap penderita, juga disebabkan kemungkinan penderita tidak datang kontrol. Keterbatasan lain yaitu tidak dilakukan pemeriksaan biopsi ginjal pada subjek penelitian ini untuk mengetahui gambaran histopatologis.

Simpulan, semakin rendah kadar albumin maka semakin besar persentase edema pada anak penderita sindrom nefrotik dalam serangan khususnya di Rumah Sakit Dr. Hasan Sadikin Bandung, RSU Cibabat, dan RSU Ujung Berung.

\section{Daftar Pustaka}

1. Clark AG, Barratt TM. Steroid responsive nephrotic syndrome. Dalam: Barrat TM, Avner ED, Harmon WE, penyunting. Pediatric nephrology. Edisi ke-4. Baltimore: Lippincott Williams \& Wilkins; 1999. hlm. 731-47.

2. Trihono PP, Alatas H, Tambunan T, Pardede S. Konsensus tata laksana sindrom nefrotik idiopatik pada anak. Edisi ke-2. UKK Nefrologi IDAI; 2008.

3. Gordillo R, Spitzer A. The nephrotic syndrome. Pediatr Rev. 2009;30:94-105.

4. Bagga A, Mantan M. Nephrotic syndrome in children. Indian J Med Res. 2005;122:13-28.

5. Roth KS, Amaker BH, Chan JCM. Nephrotic syndrome: pathogenesis and management. Ped Rev. 2002;23(7):237-47.

6. Kelsch RC, Sedman AB. Nephrotic syndrome. Pediatr Rev. 1993;14(1):30-7.

7. Vande Walle JG, Donckerwolcke RA, Koomans HA. Pathophysiology of edema formation in children with nephrotic syndrome not due to minimal change disease. J Am Soc Nephrol. 1999;10:323-31.

8. Hodson EM, Knight JF, Wilis NS, Craig JC. Corticosteroid therapy in nephrotic syndrome: a meta analysis of randomized control trials. Arch Dis Child. 2000;83:45-51.

9. WHO Multicenter Growth Reference Study Group. Interpreting growth indicators. WHO Child Growth Standards: Training Course on Child Growth Assessment. Geneva: World Health Organization; 2006.

10. Morgenstern BZ, Mahoney DW, Warady BA. Estimating total body water in children on the basis of height and weight: a reevaluation of the formulas of Mellits and Cheek. J Am Soc Nephrol. 2002;13:1884-8.

11. Vogt BA, Avner ED. Nephrotic syndrome. Dalam: Behrman RE, Kliegman RM, Jenson HB, penyunting. Nelson textbook of pediatrics. Edisi ke-18. Philadelphia: WB 
Saunders; 2007. hlm. 2190-5.

12. Haycock G. The child with idiopathic nephrotic syndrome. Dalam: Webb $\mathrm{N}$, Postlethwaite RJ, penyunting. Clinical pediatric nephrology. Edisi ke-3. New York: Oxford United Press; 2003. hlm. 341-66.

13. Niaudet P. Steroid sensitive nephrotic syndrome. Dalam: Avner ED, Harmon WE,
Niaudet $\mathrm{P}$, penyunting. Pediatric nephrology. Edisi ke-5. Philadelphia: Lippincott William \& Wilkins; 2004. hlm. 543-73.

14. Kher KK. Nephrotic syndrome Dalam: Kher KK, Makker SP, penyunting. Clinical pediatric nephrology. New York: McGraw-Hill Inc; 1992. hlm. 137-74. 